\title{
Nitrogen Fixation in Cereals
}

\author{
Mónica Rosenblueth ${ }^{1}$, Ernesto Ormeño-Orrillo², Aline López-López ${ }^{3}$, Marco A. Rogel'1, \\ Blanca Jazmín Reyes-Hernández', Julio C. Martínez-Romero', Pallavolu M. Reddy ${ }^{4}$ and \\ Esperanza Martínez-Romero ${ }^{1 *}$
}

${ }^{1}$ Center for Genomic Sciences, Universidad Nacional Autónoma de México, Cuernavaca, Mexico, ${ }^{2}$ Laboratorio de Ecología Microbiana y Biotecnología, Departamento de Biología, Facultad de Ciencias, Universidad Nacional Agraria La Molina, Lima Peru, ${ }^{3}$ Centro de Investigación en Genética y Ambiente, Universidad Autónoma de Tlaxcala, Tlaxcala, Mexico, ${ }^{4}$ The Energy and Resources Institute, India Habitat Centre, New Delhi, India

Cereals such as maize, rice, wheat and sorghum are the most important crops for human nutrition. Like other plants, cereals associate with diverse bacteria (including nitrogen-fixing bacteria called diazotrophs) and fungi. As large amounts of chemical fertilizers are used in cereals, it has always been desirable to promote biological nitrogen fixation in such crops. The quest for nitrogen fixation in cereals started long ago with the isolation of nitrogen-fixing bacteria from different plants. The sources of diazotrophs in cereals may be seeds, soils, and even irrigation water and diazotrophs have been found on roots or as endophytes. Recently, culture-independent molecular approaches have revealed that some rhizobia are found in cereal plants and that bacterial nitrogenase genes are expressed in plants. Since the levels of nitrogen-fixation attained with nitrogen-fixing bacteria in cereals are not high enough to support the plant's needs and never as good as those obtained with chemical fertilizers or with rhizobium in symbiosis with legumes, it has been the aim of different studies to increase nitrogenfixation in cereals. In many cases, these efforts have not been successful. However, new diazotroph mutants with enhanced capabilities to excrete ammonium are being successfully used to promote plant growth as commensal bacteria. In addition, there are ambitious projects supported by different funding agencies that are trying to genetically modify maize and other cereals to enhance diazotroph colonization or to fix nitrogen or to form nodules with nitrogen-fixing symbiotic rhizobia.

Keywords: rice, corn, wheat, sorghum, diazotrophic bacteria, root colonization, Rhizobium, Burkholderia

\section{INTRODUCTION}

Cereals are grasses from the Poaceae family that were domesticated several thousand years ago in different geographical regions in order to take advantage of the edible components of their grain. Maize, rice, wheat, and sorghum are the most widely grown cereals consumed by humans and this review will focus on these crops. Nitrogen availability often limits cereal crop production. Adding nitrogen to crops has enhanced food production and has consequently increased the human population. In fact, the Haber-Bosch process that produces nitrogen fertilizers industrially has been called the detonator of human population growth (Smil, 2002; Erisman et al., 2008). Increases in food production are urgently needed, yet fertilizers have already been overused, are expensive and polluting. Trends in crop management and genetics predict that crop production will not meet projected food needs in 2050 (Ray et al., 2013). Higher agricultural production will require enormous additional inputs of nitrogen. Cereal production is highly dependent on 
chemical nitrogen fertilizers and the excessive use of these fertilizers is negatively impacting human and environmental health, including significant effects on the generation of greenhouse gasses and a reduced ozone layer (Reddy et al., 2002; Stokstad, 2016). With the future menaces of a decline in petroleum reserves used in the Haber-Bosch process to produce inorganic fertilizers, besides the low efficiency with which plants use chemical nitrogen fertilizers, researchers are now seriously considering alternate sources of nitrogen for crop production.

Biological nitrogen fixation (BNF) is a potentially attractive alternative source of nitrogen for cereal production (Ladha and Reddy, 1995; Beatty and Good, 2011; Rogers and Oldroyd, 2014). In fact, BNF by diazotrophic bacteria, which reduce dinitrogen to ammonium using nitrogenase enzyme systems, is the major contributor to the nitrogen economy of the biosphere, accounting for $30-50 \%$ of the total nitrogen in crop fields (Ormeño-Orrillo et al., 2013). Nitrogen fixation is an energetically expensive process. In theory, nitrogen fixation could fall under the black queen hypothesis (Morris et al., 2012). This hypothesis predicts that in communities of free-living microorganisms, there are only a few "helpers" that have costly functions, such as nitrogen fixation, that support the "beneficiaries" that are dependent on them for nitrogen supplies (Morris et al., 2012). Consequently, diazotrophs generally correspond to minor components of the ecosystems. Diazotrophs are found among alphaproteobacteria, gammaproteobacteria, Firmicutes, betaproteobacteria, and cyanobacteria but do not seem to be the most abundant (dominant) bacteria in plant rhizospheres, so there are possibilities for increasing nitrogen-fixation by favoring their populations. To enhance their competitiveness, plants may be selected or modified to increase exudation of nutrients that would favor the growth of diazotrophs (see below). Additionally, regular inoculation with diazotrophs as is common for legumes, could provide enough bacterial cells for the plant even if bacteria do not persist long in soils. Besides, low soil persistence may not be a disadvantage because it would allow subsequent introductions of more efficient symbionts as inoculants. Inoculant formulations and survival of inoculated bacteria are not within the scope of this review.

Removing plant products from agricultural fields leads to nitrogen and other nutrient deficiencies. Therefore, achieving nitrogen fixation in cereals, like that which occurs in legumes, has been a long-cherished goal and has been considered as a holy "grail" (Triplett, 1996). A huge interest in rice nitrogen fixation is reflected in books devoted to this subject (Khush and Bennett, 1992; Ladha and Reddy, 2000). For many years, researchers have isolated, identified and tested a very large diversity of rhizospheric or endophytic isolates from plants. The practical aim has been to identify nitrogen-fixing bacteria that could be used as crop inoculants, but this has had limited practical success. The experience from efforts to increase nitrogen fixation in legumes showed contrasting results. Hypernodulating soybean plants resulted in diminished yields in some cases (Pracht et al., 1994), but in others there was an increased productivity in subsequent crops (Song et al., 1995).

Diverse microbes are found associated with plants (Bulgarelli et al., 2012, 2013, 2015; Lundberg et al., 2012; Peiffer et al.,
2013). There are comprehensive reviews on rhizospheric microbiota (Berg, 2009; Saharan and Nehra, 2011; Mendes et al., 2013), diazotrophs (Santi et al., 2013) and endophytes (residing inside plant tissues, Rosenblueth and MartínezRomero, 2006; Guo et al., 2008; Liu et al., 2017a) of diverse plants including cereals, all focusing on bacteria. Rhizospheric and endophytic bacteria contribute to plant growth promotion by producing plant hormones, inhibiting pathogens or by enhancing mineral availability (Matiru and Dakora, 2004; Rosenblueth and Martínez-Romero, 2006; Friesen et al., 2011). In most cases, there is not sufficient evidence to consider that nitrogen fixation is a leading cause of plant growth promotion. For example, there are many reports on the growth-promoting effects of Azospirillum inoculation in maize, wheat, rice, and sorghum but these will not be reviewed here because the main beneficial effects are not primarily attributed to nitrogen fixation.

In general, the contribution of nitrogen fixation in nonlegumes is limited, however, Beijerinckia spp. inoculants promoted significant increases in nitrogen content in some maize hybrids (Govedarica, 1990). In contrast to what occurs in nodules, it is common that free-living nitrogen-fixing bacteria (diazotrophs) do not excrete nitrogen compounds to the host plant with ammonium instead being assimilated and used by bacteria for their own growth. The use of genetically modified bacteria was shown to improve plant growth through nitrogen fixation. For example, ammonium excreting Azospirillum exhibited enhanced nitrogen supply to wheat plants (Van Dommelen et al., 2009). Similar mutants of Azospirillum, Kosakonia, Pseudomonas, and Azotobacter (Zhang et al., 2012; Setten et al., 2013; Geddes et al., 2015; Ambrosio et al., 2017; Bageshwar et al., 2017) proved capable of stimulating plant growth. We would recommend obtaining ammonium-excreting mutants of Paraburkholderia, Herbaspirillum, or Azoarcus as well, to test if they also improve plant growth through nitrogen fixation. Recently, Setten et al. (2013) engineered a rootcolonizing non-diazotrophic endophyte, Pseudomonas protegens Pf-5, by transferring a stretch of DNA with 52 genes including the nif gene cluster from $P$. stutzeri (Vermeiren et al., 1999). The modified $P$. protegens strain fixed nitrogen constitutively, even in the presence of combined nitrogen, and released significant quantities of ammonium into the surrounding medium. In greenhouse tests, Fox et al. (2016) demonstrated increased yields in maize and wheat inoculated with this engineered strain, and ${ }^{15} \mathrm{~N}$ isotope dilution analysis confirmed that this positive effect was clearly due to nitrogen fixation in roots.

In this review we present additional information about associative nitrogen fixation as well as studies on the genetic modification of cereals directed toward obtaining nitrogen-fixing plants by the transfer of nitrogenase or nodulation genes into plants.

\section{SOURCES OF DIAZOTROPHIC BACTERIA}

Bacteria can get on to the plants either by root colonization from soil carryover, leaf litter (Pfeiffer et al., 2013), inoculation 
or via seed transmission. Seed endophytes can migrate from the seed and colonize the plant xylem but can also migrate from beneath the seed coats with the emerging root or even after the seed has germinated (Johnston-Monje and Raizada, 2011) and colonize the rhizoplane and rhizosphere. Johnston-Monje and Raizada (2011) found that only a few endophytes are able to spread from the root vascular tissue into the rhizosphere. The contribution of seed endophytes when colonizing the rhizosphere may be better observed in soils with low bacterial diversity.

Seed-borne pathogens spread and perpetuate bacteria in new plant generations, similarly seeds may also carry beneficial bacteria that may be inherited to new generations. Nonpathogenic seed bacteria have been identified in Phaseolus vulgaris, maize, rice, wheat, alfalfa, and other plants (Okunishi et al., 2005; Rijavec et al., 2007; Johnston-Monje and Raizada, 2011; Hardoim et al., 2012; López-López et al., 2012; Liu et al., 2017b; López et al., 2018). Previous analyses of seed endophytes have shown a large diversity of bacteria (Rijavec et al., 2007; Johnston-Monje and Raizada, 2011; López-López et al., 2012; Rosenblueth et al., 2012; Chimwamurombe et al., 2016). Seed isolates from different plants are able to produce auxins, gibberellins, siderophores and ACC deaminase, solubilize phosphates, protect plants against pathogens and fix nitrogen (Zawoznik et al., 2014; Díaz Herrera et al., 2016; Khalaf and Raizada, 2016; Shahzad et al., 2016; Wang et al., 2016; Liu et al., 2017b; Verma et al., 2017).

There are very few studies that analyze bacterial genes required for seed colonization (Molina et al., 2006; Peralta et al., 2016). A P. putida mutant in a secretion system had reduced capacity to colonize maize seeds (Molina et al., 2006). Maize rhizospheric bacteria are more numerous and more diverse (Chelius and Triplett, 2001; Gomes et al., 2001; Schmalenberger and Tebbe, 2003; Chauhan et al., 2011; Pereira et al., 2011; Li et al., 2014) than seed endophytes (Rijavec et al., 2007; Johnston-Monje and Raizada, 2011; Rosenblueth et al., 2012), suggesting a bottleneck in the acquisition of bacteria by seeds.

Seeds may also be colonized by bacteria present on the surfaces of stems, flowers, and fruits (Compant et al., 2011; Hardoim et al., 2012; Mitter et al., 2017), as well as from pollen grains, which also harbor bacteria (Madmony et al., 2005; Fürnkranz et al., 2012) that can colonize the ovules after pollination (Agarwal and Sinclair, 1996). Rhizospheric bacteria seem to be mainly acquired from the soil or from leaf litter (Pfeiffer et al., 2013). Dependant on crop management history (Isobe and Ohte, 2014) or soil pH (Andrew et al., 2012; Hardoim et al., 2012). Root endophytic bacteria are acquired from the rhizosphere and a fraction of them can move through the xylem to colonize aerial parts, including seeds (James et al., 2002; Okunishi et al., 2005; Compant et al., 2011; Liu et al., 2017a).

To study novel sources of maize associated bacteria, we analyzed the contribution of irrigation and identified bacteria from the maize rhizoplane by sequence analysis of 16S rRNA gene amplicons from plants that were irrigated with water from two different Mexican rivers, Apatlaco and Tembembe (Merino-Flores, 2012). The maize rhizoplane irrigated with river water had river-borne bacteria, previously identified as
Pseudomonas (Sachman-Ruiz et al., 2009) and there were common bacterial species in maize roots irrigated with water from both rivers, such as Acidovorax, Commamonas, and Herbaspirillum (Figure 1). From controls, irrigated with sterile water, only alphaproteobacteria from the Rhizobiales order were observed (Figure 1) and identified as Methylobacterium and Rhizobium. As these bacteria were recovered from plants that were maintained under sterile conditions in sterile vermiculite, irrigated with sterile water and derived from surface-disinfected seeds, they probably derived from kernel endophytes that found their way out of seeds to colonize the rhizosphere. However, seed-borne bacteria were outcompeted in roots by irrigationborne bacteria, thus lowering the proportion of seed bacteria in the final composition of the plant microbiome from river water irrigated plants. Bacterial genera identified in the maize rhizoplane by a culture-dependent approach (Pereira et al., 2011) were included in this comparison (Figure 1). Pereira et al. (2011) found many Firmicutes in the rhizoplane, similar to other reports (Han et al., 2011; Compant et al., 2013). Previously we reported that each kernel had a different subset of endophytes, even when kernels belonged to the same cob (Rosenblueth et al., 2012). This indicated that not all seedlings in a germinating population would have the same bacteria, that would add biodiversity to plants and perhaps bring adaptive advantages.

\section{CULTURE-INDEPENDENT IDENTIFICATION OF DIAZOTROPHS IN CEREALS}

By using a culture-independent approach, a better representation of existing diazotrophs may be obtained while the analysis of nifH transcripts has provided results on active diazotrophs. This approach based on nif gene amplification and sequencing has been used to identify nitrogen-fixing bacteria associated with rice, sorghum, wheat and maize. There are no universal nif gene primers and diverse primers should be used to identify different genera or nitrogen-fixing bacterial families.

In rice, a diversity of putative diazotrophs have been revealed by PCR amplification and sequencing of metagenomic DNA from roots. Ueda et al. (1995) reported 23 nifH sequences from Oryza sativa cv. Nihonn in Japan which grouped with deltaproteobacteria (Desulfovibrio), gammaproteobacteria (Klebsiella-like, Azotobacter) and alphaproteobacteria (Thiobacillus-like) genes, the former two groups being the most abundant. Sixteen nifH sequences from rice analyzed by Engelhard et al. (2000) from DNA from root macerates clustered with genes from alphaproteobacteria (Bradyrhizobium, Azorhizobium, and Rhizobium) and betaproteobacteria (Azoarcus) as well with those from Firmicutes (related to Clostridium). Proteobacteria was also dominant among nifH sequences obtained from DNA extracted from rice in Thailand with betaproteobacteria being the most abundant (e.g., Herbaspirillum) (Rangjaroen et al., 2014).

Diazotrophs expressing nitrogenase reductase mRNA in association with rice have been identified. Elbeltagy 


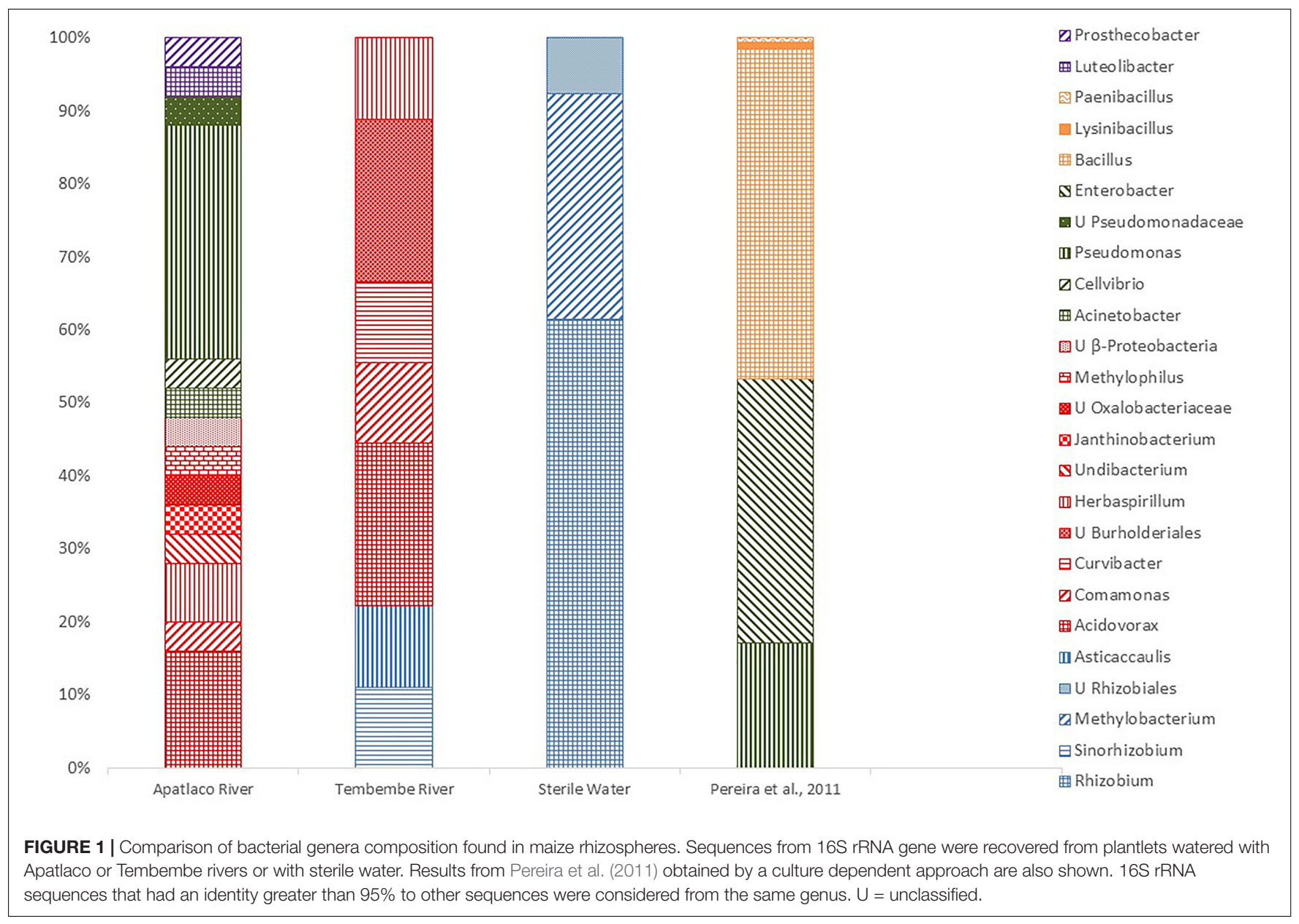

and Ando (2008) sequenced 117 nifH transcripts from $O$. sativa cv. Sprice and cv. Tetep grown in Japan and found that most sequences $(>70 \%)$ belonged to a novel cluster related to Geobacter sulfurreducens (deltaproteobacteria), other sequences were affiliated with alphaproteobacteria (Bradyrhizobium and Methylocystis), betaproteobacteria (Azovibrio), gammaproteobacteria (Azotobacter), Firmicutes (related to Heliobacterium) and a polyphyletic group encompassing anaerobes. Azoarcus seemed as a dominant active nitrogen fixer in mixed rhizosphere/root samples from rice cultivated in a paddy soil in China (Wartiainen et al., 2008) while Mårtensson et al. (2009) found an abundance of proteobacteriarelated sequences from the alpha, beta and gamma subdivisions as well as fewer sequences from a polyphyletic anaerobe group when studying samples from the same site just one year later. In a proteomic approach, dinitrogen reductase proteins from Bradyrhizobium, Magnetospirillum, and Azospirillum have been detected in the rhizosphere of rice growing in Philippines (Knief et al., 2012).

Among 245 nifH sequences obtained from soil DNA of sorghum (Sorghum bicolor) rhizospheres cultivated in Brazil, Coelho et al. (2008) found mostly proteobacterial diazotrophs. Sequences were related to bacteria from the Rhizobiales, Burkholderiales, Sphingomonadales, Rhodospirillales,
Enterobacteriales, and Bacillales. Diazotrophs with nifH sequences $>98 \%$ identical to those of Bradyrhizobium and Rhizobium were common.

The identity of diazotrophs inhabiting the rhizosphere and different tissues of maize (roots and stems) was determined by Roesch et al. (2008) by sequencing nifH amplified from DNA extracts. They found that Proteobacterial sequences were the most prevalent in all analyzed tissues and also in the rhizosphere. Members of the alpha, beta, gamma, or delta subdivisions were present but the two former subdivisions were numerically dominant. The most abundant genera were Azospirillum, Bradyrhizobium, Herbaspirillum, Ideonella, Klebsiella, and Raoultella.

Naturally-occurring diazotrophs were analyzed in all previous studies but some studies have evaluated the expression of nitrogenase genes of inoculated strains. You et al. (2005) reported the expression of nifH of Herbaspirillum sp. B501 in shoots of wild rice (O. officinalis) after inoculation of the bacteria to the seeds. Azospirillum brasilense FP2 applied to wheat (Triticum aestivum) was shown to express the nifHDK operon when colonizing roots (Camilios-Neto et al., 2014). Another inoculant strain, Herbaspirillum seropedicae SmR1, was also able to express the same genes when attached to wheat roots (Pankievicz et al., 2016). 
From these studies, it can be concluded that a wide diversity of bacteria possessing nifH genes are associated with cereals. It is worth noting that a significant proportion of the sequences obtained form clusters that are unrelated to known taxonomic groups. Functional molecular analyses in rice have shown that not all of these microorganisms are active at nitrogen fixation in association with the plant. The taxonomic composition of the active diazotrophs varies from plant to plant but Proteobacteria are always present and a polyphyletic group of anaerobes are very common. The presence of the latter group may be related to the nature of rice cultivation under water. Alphaproteobacteria from the Rhizobiales order, specifically of the Bradyrhizobium genus, have been found as active nitrogen fixers both by transcriptomic and proteomic approaches. Interestingly, in sugarcane, another member of the Poaceae family, bradyrhizobia also express nitrogen fixation genes in planta (Thaweenut et al., 2011; Fischer et al., 2012). Rhizobia in general have been used as biofertilizers in agriculture for more than a century and it will be worth exploring if bradyrhizobial inoculants can be developed for cereals.

\section{DIAZOTROPHS MAY BE HUMAN PATHOGENS}

It is not uncommon to isolate human or plant pathogens from plants and in many cases they are efficient growth promoting bacteria. Their use in agriculture should not be encouraged. Among the nitrogen-fixing bacteria isolated from cereals there are human pathogens or potential human pathogens (Berg et al., 2005), such as Burkholderia cepacia and Klebsiella variicola (Rosenblueth et al., 2004, 2011; Kutter et al., 2006; MartínezRomero et al., 2018). B. cepacia complex (BCC) includes seventeen species, some of them responsible for potentially lethal pulmonary infection in immuno-compromised or cystic fibrosis patients, and others are causative agents of infection in animals and plants (Sawana et al., 2014). Members of this complex are generally good colonizers of plant rhizosphere and possess traits to improve plant growth (Fiore et al., 2001; Mendes et al., 2007). For a long time, B. vietnamensis, found in the rhizosphere and rhizoplane of maize, coffee, and sorghum plants (Gillis et al., 1995) was recognized as the only nitrogen-fixing species belonging to the BCC. However, new species of plantassociated Paraburkholderia diazotrophs have been reported, such as $P$. unamae, $P$. tropica, $P$. xenovorans from rhizospheric or endophytic association with maize, coffee, sorghum, or sugarcane (Perin et al., 2006). This group of bacteria has been found to comprise mainly environmental and plant-associated isolates (Baldani et al., 2000; Chen et al., 2003; Govindarajan et al., 2006). The presence of two transmissible virulence factor genes such as the cblA (encoding giant cable pili) and the epidemic strain marker regulator (esmR) identified among clinical isolates of opportunistic pathogens of $B$. cenocepacia and other species of the BCC have not been detected by PCR amplification and ${ }^{32} \mathrm{P}$ hybridization in the environmental diazotrophic isolates of B. unamae and B. tropica. Thus, the lack of the aforementioned pathogenic traits supports the potential for using them as plant growth-promoting bacteria, since they were shown to have the ability to improve maize growth (Perin et al., 2006). Genomic analysis of the plant-associated Burkholderia and the pathogen B. cenocepacia for the occurrence of virulence determinants implicated in pathogenesis as well as the functional tests to determine pathogenicity showed that these two phylogenetic groups of Burkholderia belong to two distinct lineages. Mutualistic strains did not possess the virulence determinants tested and were susceptible to the vast majority of antibiotics. They did not kill Caenorhabditis elegans nor lyse of HeLa cells, unlike the pathogen B. thailandensis (Angus et al., 2014). Abundance of phylogenetic, biochemical, and molecular evidences for the occurrence of two different lineages within the genus Burkholderia finally led to a taxonomic revision with a split in the genus and allowed the environmental group to be renamed as Paraburkholderia, which nevertheless still includes a few human clinical isolates (Estrada-de los Santos et al., 2013; Angus et al., 2014; Sawana et al., 2014). Thus, some of the isolates that were formerly classified as Burkholderia species may still be considered suitable candidates as plant growth promoters.

Klebsiella has been isolated from several distinct plants (Chelius and Triplett, 2000; Martínez et al., 2003; Rosenblueth et al., 2004; Martínez-Romero et al., 2015; Liu et al., 2017b; Reyna-Flores et al., 2018). However, its use in agriculture has been discouraged since some strains of Klebsiella were found to be pathogens or opportunistic pathogens of humans and animals (Martínez et al., 2004; Davidson et al., 2015; Martínez-Romero et al., 2018). Comparative genomic analysis of $K$. variicola 342 (originally reported as K. pneumoniae) and K. pneumoniae MGH78578 showed that the latter cannot fix nitrogen, and there was a difference between these two species in the presence of genes essential for attachment, transport, and secretion. K. variicola 342 possesses genes that are involved in processing plant-derived cellulose and aromatic compounds but did not have a Type III secretion system that can be used to secrete effector proteins into the cytoplasm of eukaryotic cells, promoting their infection, nor genes encoding effector proteins. It was resistant to antibiotics (Fouts et al., 2008). However, in the experiments conducted in mice to test pathogenicity, $K$. variicola 342 caused urinary tract infection like the clinical isolate C3091 but showed a significantly lower level of lung infection.

On the other hand, other plant-associated bacteria such as Azospirillum (Okon and Itzigsohn, 1995), Herbaspirillum (Baldani et al., 2000), Gluconacetobacter diazotrophicus (Muthukumarasamy et al., 2005) and Azoarcus (ReinholdHurek and Hurek, 1997) are considered safe and they are used as inoculants in agriculture. Azoarcus and Herbaspirillum have been shown to fix nitrogen in rice (Elbeltagy et al., 2001; Hurek et al., 2002; Roncato-Maccari et al., 2003). The complete genome sequence of Herbaspirillum seropedicae SmR1, a spontaneous streptomycin resistant mutant, reveals it to be a metabolically versatile bacterium that contains genes coding for degradation of aromatic compounds. The limited number of genes related to mobile elements suggests a low rate of DNA transfer in this microorganism that is presumably due to adaptation to a stable 
microenvironment. H. seropedicae can synthesize plant-growth promoting substances such as auxins and gibberellins, and fixes nitrogen. It has a variety of protein secretion systems involved in plant bacterial recognition (Pedrosa et al., 2011). Likewise, Azoarcus sp. BH72 genome contains few mobile elements in comparison to many soil bacteria or pathogens, which indicates that its genome has low plasticity. The strain appears to be "disarmed" compared to plant pathogens due to lack of known toxins as well as Types III and IV secretion systems. The lack of a $N$-acyl homoserine lactone-based communication system argues for a rather exclusive microhabitat and, the presence of genes coding for nitrogen fixation, chemotaxis, iron acquisition and biocontrol offer insight into genomic strategies for an endophytic life style and allow identification of various features that contribute to its interaction with plants (Krause et al., 2007).

Rhizobia are also considered safe and have been used in agriculture as legume inoculants for more than one hundred years and their use in non-legumes is recommended as well. Bradyrhizobia have been found to be associated with wild rice in Africa (Chaintreuil et al., 2000), sweet potatoes in Japan (Terakado-Tonooka et al., 2008) and sugarcane in Brazil (Fischer et al., 2012). Some Rhizobium genotypes are very efficient at colonizing maize roots (Gutiérrez-Zamora and Martínez-Romero, 2001; Rosenblueth and Martínez-Romero, 2004). Rhizobia promote rice growth (Yanni et al., 1997) perhaps due to nitrogen fixation, and we suppose that bradyrhizobia may contribute fixed nitrogen to plants since some bradyrhizobial strains are capable of fixing nitrogen in the free-living state. A general brief overview of the rhizobial genetic repertoire to colonize non-legumes was published (López-Guerrero et al., 2013).

\section{PLANTS AS DETERMINANTS OF BACTERIAL INTERACTIONS}

Nitrogen fixation is highly variable depending on the associated diazotroph and the plant variety, but the host plant exerts a determinant effect by supplying the carbon and energy source for bacterial growth and nitrogen fixation. Aluminum or acid tolerant plants were found to sustain high levels of nitrogen fixation due to the exudation of dicarboxylic acids from their roots (Christiansen-Weniger et al., 1992). The maize rhizosphere is a habitat favorable for diazotroph proliferation due to high quantities of exudates [accounting for 20-40\% of all photosynthate (Stevenson and Cole, 1999)], although unbalanced in $\mathrm{C}$ and $\mathrm{N}$. Root exudates and plant secondary metabolites have a selective or inhibitory effect on bacteria (Guntli et al., 1999; Bending and Lincoln, 2000). Sphingomonadales prefer root exudates from monocotyledonous plants rather than from other plants (Haichar et al., 2008), but it may be premature to make general statements. Plant species, genotype, and age have effects on root microbiota (Dalmastri et al., 1999; Cavaglieri et al., 2009; Hartmann et al., 2009; Peiffer et al., 2013; Chaparro et al., 2014; JohnstonMonje et al., 2014; Wagner et al., 2016; Pfeiffer et al., 2017).
Phytoalexins and salicylic acid that mediate plant defense in legumes have inhibitory effects on plant-Rhizobium interactions (Parniske et al., 1991; González-Pasayo and Martínez-Romero, 2000; Stacey et al., 2006; Lebeis et al., 2015), but less is known about the effects of defense alkaloids on diazotrophs in cereals. Maize bacillus and rhizobial endophytes were found to be resistant to MBOA (Rosenblueth and MartínezRomero, 2004), which is a toxic allelochemical in maize (Abel et al., 1995). Salicylic acid from plants restricts bacterial root colonization (Lebeis et al., 2015). Additionally, plants may interfere or stimulate quorum sensing signaling among bacteria (Bauer and Mathesius, 2004; Venturi and Keel, 2016), which may have significant effects by changing bacterial gene expression.

\section{PROSPECTS FOR ENGINEERING CEREAL PLANTS}

Besides using associated bacteria to provide nitrogen to cereals other strategies involving the genetic modification of plants have been considered and are reviewed here. Two major approaches, transferring nitrogenase genes into crop plants and the development of the root nodular symbiosis in cereals, were envisioned as important avenues for achieving this target (Ladha and Reddy, 1995, Ladha and Reddy, 2000; Beatty and Good, 2011). Indeed, all these options have been considered and initial feasibility studies were conducted under the auspices of the International Rice Research Institute-coordinated multinational frontier project on "Assessing Opportunities for Nitrogen Fixation in Rice" during 1994-2001 (see Ladha and Reddy, 2000). However, major breakthroughs in the genomics of diazotrophs and the genetics of nitrogen fixation, as well as the processes involved in legume-rhizobia symbioses in recent years have opened up new avenues to tackle this problem much more systematically and have prompted the formulation of more workable schemes aimed at achieving this goal (Beatty and Good, 2011).

For the goal of generating nitrogen-fixing cereal crops, several analogous projects funded by the Bill and Melinda Gates Foundation (BMGF, United States), the National Science Foundation (NSF, United States), the Biotechnology and Biological Sciences Research Council (BBSRC, United Kingdom) and the Indian Council of Agricultural Research (ICAR, India) have recently been initiated with differential emphasis on the choice of crop or experimental system. Among these, the first approach considers assembling of an active nitrogenase in plants through the incorporation and expression of bacterial genetic machinery to encode and support functional nitrogenase system. Nitrogen fixation is a highly energy demanding process, and so chloroplasts and mitochondria are envisaged as suitable sites for nitrogen fixation since they can meet the energy requirements for nitrogenase in plant cells. Nitrogenase is extremely sensitive to oxygen and irreversibly inactivated in air, and so the oxygen evolved by chloroplasts during photosynthesis may be detrimental to the maintenance of nitrogenase enzyme complex 
integrity. Thus, expressing functional nitrogenase in chloroplasts requires temporal (day/night) separation of photosynthesis and nitrogen fixation by confining nif gene expression only to dark periods (nights) or, alternatively, by spatially restricting nif gene expression to non-photosynthetic tissues such as the root system. As a proof of concept using yeast (a non-photosynthetic organism) as a model system, López-Torrejón et al. (2016) engineered nifH, nifM, nifS, and nifU from Azotobacter vinelandii into this eukaryotic cell and showed that active nitrogenase $\mathrm{Fe}$ protein can be produced if $\mathrm{NifH}$ polypeptide is targeted to the mitochondrial milieu jointly with the NifM maturase. They further demonstrated that for the generation of an active Fe protein, concomitant transfer of the NifH-specific $\mathrm{Fe}-\mathrm{S}$ cofactor synthesizing protein components NifU and NifS into mitochondria is not essential, because $\mathrm{NifH}$ is able to acquire/incorporate endogenously generated mitochondrial $\mathrm{Fe}-\mathrm{S}$ clusters. In a subsequent study, Buren et al. (2017) targeted a minimum set of nine $A$. vinelandii nif genes (nifH, nifD, nifK, nifU, nifS, nifM, nifB, nifE, and nifN) into mitochondria and demonstrated successful formation of NifDK tetramer, an essential first step in assembling a functional nitrogenase in a eukaryotic cell. nif gene transfer has also been attempted in plants. Ivleva et al. (2016) expressed $\mathrm{NifH}$ protein together with nifM in chloroplasts of tobacco plants, generating functional $\mathrm{NifH}$, although with low activity. Recently, Allen et al. (2017) demonstrated the feasibility of expressing the complete range of biosynthetic and catalytic nitrogenase (Nif) proteins as mitochondrial targeting transit peptide-Nif fusions in tobacco leaves. Studies in both yeast and tobacco showed, however, that NifD polypeptide is prone to degradation in eukaryotic cells (Allen et al., 2017; Buren et al., 2017), thus warranting a need for optimizing its amino acid sequence to improve stability without compromising catalytic activity. We suggest that readers refer to the excellent recently published review articles for a comprehensive account of the strategy for nif gene transfer to eukaryotes (Curatti and Rubio, 2014; Buren and Rubio, 2017).

The second approach envisions the development of legumelike root-nodule symbioses (RNS) in cereal crop plants (Reddy et al., 2013; Rogers and Oldroyd, 2014). This approach is based on contemporary knowledge on the development of the endosymbiotic associations of most land plants with endomycorrhizal fungi that form phosphate-acquiring arbuscular mycorrhizae (AM) in cereals and legumes, and with diverse diazotrophic rhizobia, to form nitrogen-fixing RNS in legumes. Genetic constituents that are critical for triggering initial processes for the development of AM symbiosis (AMS) are similar in both legumes and rice, and possibly in other cereals too (Gutjahr et al., 2008). Moreover, in legumes, these same genetic components play a critical role in aiding initial stages of RNS development as well. Thus, genetic elements that participate in promoting both AMS and RNS development constitute the "common symbiosis pathway" (CSP; Markmann and Parniske, 2008). Current lines of research in cereals are making use of functionally conserved genetic constituents of the CSP as a foundation to extend genetic networks to assemble a complete signaling pathway to support legume-like RNS in cereal crops
(Reddy et al., 2013; Rogers and Oldroyd, 2014; Delaux et al., 2015; Mus et al., 2016).

An alternative option is to develop cereals that promote the growth of diazotrophs. Since the population density of endophytic bacteria in plant tissues is too low to support adequate nitrogen fixation, it is important to design systems that aid greater colonization of diazotrophic endophytes for improved nitrogen fixation in the crop plants. To achieve this, it is critical to improve the chances that the inoculated diazotroph will selectively colonize the crop plant. This is essential because newly introduced bacterial strains are usually out-competed by the native microbial communities in the rhizosphere of plants. This impediment could be surmounted by engineering plants to produce a specific metabolite and thus create a "biased rhizosphere" to favor the growth of an introduced diazotroph able to use the novel metabolite (Rossbach et al., 1994).

\section{WOULD CARBON COSTS INCURRED DUE TO IN PLANTA NITROGEN FIXATION REDUCE CROP YIELDS IN CEREALS?}

Nitrogen fixation is a highly energy requiring process and the factors that limit symbiotic nitrogen fixation have been analyzed in only few legumes. For example, oxygen diffusion was found to limit carbon metabolism and nitrogen fixation in nodules (Vance and Heichel, 1991). In legumes such as soybean, energy costs are significant for both $\mathrm{N}_{2}$ fixation and $\mathrm{NO}_{3}$ assimilation but are apparently somewhat greater for the former. Layzell (2000) estimated that in soybean, $5 \mathrm{CO}_{2}$ are released per $\mathrm{N}_{2}$ fixed, while during nitrate assimilation approximately $5.7 \mathrm{CO}_{2}$ are released per nitrogen assimilated in non-photosynthetic tissue, and $0-2.9 \mathrm{CO}_{2}$ per nitrogen assimilated in photosynthetic tissue (see Ladha and Reddy, 2000 for detailed discussion). While there is no doubt that supplying ammonia $\left(\mathrm{NH}_{3}\right)$ as a nitrogen source for plants reduces the energy requirement for nitrogen assimilation, the proper comparison that should most often be made (except for paddy rice) is between dinitrogen $\left(\mathrm{N}_{2}\right)$ and nitrate as nitrogen sources, since nitrate is the most common alternative nitrogen source available in aerated soils. In plants that use nitrate as a source of nitrogen, nitrate first needs to be converted to ammonia to allow the synthesis of amino acids. Nitrate uptake and its conversion into ammonia is an energy requiring process. It has been estimated that carbon or energy costs for the conversion of $\mathrm{NO}_{3}$ to $\mathrm{NH}_{4}{ }^{+}$is: $\Delta \mathrm{G}=-605 \mathrm{~kJ} \mathrm{~mol}^{-1}$ (Pate et al., 1979; Kennedy and Cocking, 1997). Likewise, in the case of nitrogen-fixing legumes, $N_{2}$ is first converted into $\mathrm{NH}_{4}^{+}$, and then into amino acids. It is calculated that carbon or energy costs for the conversion of $\mathrm{N}_{2}$ to $\mathrm{NH}_{4}{ }^{+}$is about $-687 \mathrm{~kJ} \mathrm{~mol}^{-1}$. These theoretical carbon or energy costs for conversion of $\mathrm{NO}_{3}$ and $\mathrm{N}_{2}$ to $\mathrm{NH}_{4}{ }^{+}$are quite similar.

In legumes, there is no experimental evidence to support the contention that nitrogen fixation reduces yield. Fertilization 
in field conditions with various forms of combined nitrogen rarely produced any significant advantage to final yield of plants (Vance and Heichel, 1991). Under greenhouse conditions as well, no significant yield differences were observed when the plants were grown on dinitrogen versus nitrate as a nitrogen source (Gibson, 1966). This indicates that legumes using BNF rather than nitrate nitrogen suffer no obvious yield penalties. Urea and ammonium sulfate are normally used to fertilize rice. An important point to note here is that in spite of the greater energy requirement for nitrate assimilation (compared to ammonia assimilation), rice yields are better when grown on nitrate combined with ammonia as compared to ammonia alone (Xiaoe and Xi, 1991; Ancheng et al., 1993). The fact that no yield penalty exists for rice grown on nitrate and ammonia rather than ammonia alone suggests that energy may not be limiting.

The ability of plants to compensate for extra energy consumption cannot be ignored, as photosynthetic systems saturate at relatively low light intensity. Nevertheless, since source and sink metabolisms are tightly coupled, it is reasonable to assume that the extra energy consumption by roots would stimulate the production of biomass in shoots. It is well established that equilibrium between photosynthetic sugar synthesis in the chloroplast-containing leaf cells (source tissues) and sugar consumption by roots, fruits and grains (sink tissues) must be maintained for sustaining plant growth and survival. In plants under optimal light and at the normal carbon dioxide levels, sink limitation occurs when the rate of photosynthesis is limited by insufficient withdrawal of photosynthetic products generated in the green tissues through the Calvin-Benson cycle (Sawada et al., 1986; Sharkey et al., 1986; Paul and Foyer, 2001; Adams et al., 2013).

It is intuitively envisaged that a nitrogen-fixing symbiosis in rice may be such a strong sink for photosynthate that yields would be impacted. Since rice is low in protein, a much lower rate of nitrogen fixation than in protein-rich legumes will be needed, with less demand for the plant's photosynthates (Ladha and Reddy, 1995). In cereals, it has been estimated that as much as $29 \%$ of photosynthate is released as exudates by roots into the rhizosphere (Lynch and Whipps, 1990). From this, it may be inferred that cereals like rice have a capacity to sustain carbon/energy costs to support nitrogen fixation (through utilization of root exudates) without causing any strain on their productivity. Also, incidentally, in rice the actual grain yields are considerably lower than their maximum genetic potential. Therefore, in planta nitrogen-fixing attribute may not significantly impact the present yield levels (Ladha and Reddy, 2000).

\section{CONCLUSION AND PERSPECTIVES}

There has been a biotechnological interest to promote associative nitrogen fixation in non-legume crops that normally use large amounts of chemical fertilizers. Different nitrogen-fixing bacteria have been isolated from cereal roots by culture-dependent methods, and when used as plant inoculants they have varying degrees and strategies for plant growth promotion (Kennedy et al., 2004; Bhattacharjee et al., 2008; Santi et al., 2013). Some past efforts to increase nitrogen fixation in cereals by promoting pseudonodules with phytohormones failed. Notably, recently obtained ammonium excreting mutants of some plantassociated diazotrophs were effective for promoting plant growth suggesting that they became capable of supplying nitrogen to their hosts. Even though achieving geneticallymodified nitrogen-fixing cereal crops is a complex process, the approaches that are being pursued at present are creating exciting possibilities for generating such plants in the foreseeable future. If so, the global environmental benefits of a reduced chemical fertilizer usage will be large, and we suppose that detrimental ecological consequences of nitrogen fixing cereals will be minimal. Besides nitrogen, other agricultural inputs, such as phosphorus and water, may limit crop productivity. Mycorrhiza and plant cultivars with high phosphate use efficiency should be considered when developing nitrogen fixing cereals. However, we consider that not only the use of microbes and genetically modified plants will be required to achieve this goal, but a better crop management and efficient programs to control human population-growth are needed as well.

\section{AUTHOR CONTRIBUTIONS}

MR wrote part of the "Introduction" and "Sources of Diazotrophic Bacteria," contributed to the discussion and prepared the figure. EO-O wrote the part "Culture-Independent Identification of Diazotrophs in Cereals" and contributed to the discussion. AL-L wrote the part "Diazotrophs May Be Human Pathogens." BR-H and MR contributed to the discussion and performed the laboratory experiments. JM-R contributed to the discussion, searched for references, and corrected the manuscript. PR wrote the parts "Prospects for Engineering Cereal Plants" and "Would Carbon Costs Incurred Due to in planta Nitrogen Fixation Reduce Crop Yields in Cereals?" EM-R wrote the parts "Abstract," "Conclusion and Perspectives," and "Plants as Determinants of Bacterial Interactions," and also assembled the paper and coordinated the study.

\section{FUNDING}

This study was supported by the joint collaborative project India DST-Mexico CONACyT (266429 to EM-R and DST/INT/Mexico/10/2016 to PR). This study was also supported by CONACyT 253116 and PAPIIT IN207718 from DGAPA, UNAM to EM-R; DBT-India (DBT-NER/AGRI/29/2015); and ICAR (Incentivizing Research/BNF/2015-18) to PR.

\section{ACKNOWLEDGMENTS}

We thank Michael Dunn for reading the manuscript. 


\section{REFERENCES}

Abel, C. A., Wilson, R. L., and Robbins, J. C. (1995). Evaluation of Peruvian maize for resistance to European corn borer (Lepidoptera: Pyralidae) leaf feeding and ovipositional preference. J. Econ. Entomol. 88, 1044-1048. doi: 10.1093/jee/88. 4.1044

Adams, W. W. III, Muller, O., Cohu, C. M., and Demmig-Adams, B. (2013). May photoinhibition be a consequence, rather than a cause, of limited plant productivity? Photosynth. Res. 117, 31-44. doi: 10.1007/s11120-013-9849-7

Agarwal, V. K., and Sinclair, J. B. (1996). Principles of Seed Pathology. Boca Raton, FL: Lewis Publication.

Allen, R. S., Tilbrook, K., Warden, A. C., Campbell, P. C., Rolland, V., Singh, S. P., et al. (2017). Expression of 16 nitrogenase proteins within the plant mitochondrial matrix. Front. Plant Sci. 8:287. doi: 10.3389/fpls.2017.00287

Ambrosio, R., Ortiz-Marquez, J. C., and Curatti, L. (2017). Metabolic engineering of a diazotrophic bacterium improves ammonium release and biofertilization of plants and microalgae. Metab. Eng. 40, 59-68. doi: 10.1016/j.ymben.2017.01.002

Ancheng, L., Jianming, X., and Xiaoe, Y. (1993). Effect of nitrogen $\left(\mathrm{NH}_{4} \mathrm{NO}_{3}\right)$ supply on absorption of ammonium and nitrate by conventional and hybrid rice during reproductive growth. Plant Soil 15, 395-398. doi: 10.1007/BF00025066

Andrew, D. R., Fitak, R. R., Munguia-Vega, A., Racolta, A., Martinson, V. G., and Dontsova, K. (2012). Abiotic factors shape microbial diversity in Sonoran Desert soils. Appl. Environ. Microbiol. 78, 7527-7537. doi: 10.1128/AEM.014 59-12

Angus, A., Agapakis, C. M., Fong, S., Yerrapragada, S., Estrada-de los Santos, P., Yang, P., et al. (2014). Plant-associated symbiotic Burkholderia species lack hallmark strategies required in mammalian pathogenesis. PLoS One 9:e83779. doi: 10.1371/journal.pone.0083779

Bageshwar, U. K., Srivastava, M., Pardha-Saradhi, P., Paul, S., Gothandapani, S., Jaat, R. S., et al. (2017). An environment friendly engineered Azotobacter can replace substantial amount of urea fertilizer and yet sustain same wheat yield. Appl. Environ. Microbiol. 83:e00590-17. doi: 10.1128/AEM.00590-17

Baldani, V. L. D., Baldani, J. I., and Döbereiner, J. (2000). Inoculation of rice plants with the endophytic diazotrophs Herbaspirillum seropedicae and Burkholderia spp. Biol. Fertil. Soils 30, 485-491. doi: 10.1007/s003740050027

Bauer, W. D., and Mathesius, U. (2004). Plant responses to bacterial quorum sensing signals. Curr. Opin. Plant Biol. 7, 429-433. doi: 10.1016/j.pbi.2004. 05.008

Beatty, P. H., and Good, A. G. (2011). Future prospects for cereals that fix nitrogen. Science 333, 416-417. doi: 10.1126/science.1209467

Bending, G. D., and Lincoln, S. (2000). Inhibition of soil nitrifying bacteria communities and their activities by glucosinolate hydrolysis products. Soil Biol. Biochem. 32, 1261-1269. doi: 10.1016/S0038-0717(00)00043-2

Berg, G. (2009). Plant-microbe interactions promoting plant growth and health: perspectives for controlled use of microorganisms in agriculture. Appl. Microbiol. Biotechnol. 84, 11-18. doi: 10.1007/s00253-009-2092-7

Berg, G., Eberl, L., and Hartmann, A. (2005). The rhizosphere as a reservoir for opportunistic human pathogenic bacteria. Environ. Microbiol. 7, 1673-1685. doi: 10.1111/j.1462-2920.2005.00891.x

Bhattacharjee, R. B., Singh, A., and Mukhopadhyay, S. N. (2008). Use of nitrogenfixing bacteria as biofertiliser for non-legumes: prospects and challenges. Appl. Microbiol. Biotechnol. 80, 199-209. doi: 10.1007/s00253-008-1567-2

Bulgarelli, D., Garrido-Oter, R., Münch, P. C., Weiman, A., Dröge, J., Pan, Y., et al. (2015). Structure and function of the bacterial root microbiota in wild and domesticated barley. Cell Host Microbe 17, 392-403. doi: 10.1016/j.chom. 2015.01.011

Bulgarelli, D., Rott, M., Schlaeppi, K., Ver Loren van Themaat, E., Ahmadinejad, N., Assenza, F., et al. (2012). Revealing structure and assembly cues for Arabidopsis root-inhabiting bacterial microbiota. Nature 488, 91-95. doi: 10.1038/nature11336

Bulgarelli, D., Schlaeppi, K., Spaepen, S., Ver Loren van Themaat, E., and SchulzeLefert, P. (2013). Structure and functions of the bacterial microbiota of plants. Annu. Rev. Plant Biol. 64, 807-838. doi: 10.1146/annurev-arplant-050312120106

Buren, S., and Rubio, L. M. (2017). State of the art in eukaryotic nitrogenase engineering. FEMS Microbiol. Lett. 365:fnx274. doi: 10.1093/femsle/fnx274

Buren, S., Young, E. M., Sweeny, E. A., López-Torrejón, G., Veldhuizen, M., Voigt, C. A., et al. (2017). Formation of nitrogenase NifDK tetramers in the mitochondria of Saccharomyces cerevisiae. ACS Synth. Biol. 6, 1043-1055. doi: $10.1021 /$ acssynbio.6b00371

Camilios-Neto, D., Bonato, P., Wassem, R., Tadra-Sfeir, M. Z., BrusamarelloSantos, L. C., Valdameri, G., et al. (2014). Dual RNA-seq transcriptional analysis of wheat roots colonized by Azospirillum brasilense reveals up-regulation of nutrient acquisition and cell cycle genes. BMC Genomics 15:378. doi: 10.1186/ 1471-2164-15-378

Cavaglieri, L., Orlando, J., and Etcheverry, M. (2009). Rhizosphere microbial community structure at different maize plant growth stages and root locations. Microbiol. Res. 164, 391-399. doi: 10.1016/j.micres.2007. 03.006

Chaintreuil, C., Giraud, E., Prin, Y., Lorquin, J., Bâ, A., Gillis, M., et al. (2000). Photosynthetic bradyrhizobia are natural endophytes of the African wild rice Oryza breviligulata. Appl. Environ. Microbiol. 66, 5437-5447. doi: 10.1128/ AEM.66.12.5437-5447.2000

Chaparro, J. M., Badri, D. V., and Vivanco, J. M. (2014). Rhizosphere microbiome assemblage is affected by plant development. ISME J. 8, 790-803. doi: 10.1038/ ismej.2013.196

Chauhan, P. S., Chaudhry, V., Mishra, S., and Nautiyal, C. S. (2011). Uncultured bacterial diversity in tropical maize (Zea mays L.) rhizosphere. J. Basic Microbiol. 51, 15-32. doi: 10.1002/jobm.201000171

Chelius, M. K., and Triplett, E. W. (2000). Immunolocalization of dinitrogenase reductase produced by Klebsiella pneumoniae in association with Zea mays L. Appl. Environ. Microbiol. 66, 783-787. doi: 10.1128/AEM.66.2.783-787.2000

Chelius, M. K., and Triplett, E. W. (2001). The diversity of archaea and bacteria in association with the roots of Zea mays L. Microb. Ecol. 41, 252-263. doi: $10.1007 /$ s002480000087

Chen, W. M., Moulin, L., Bontemps, C., Vandamme, P., Béna, G., and BoivinMasson, C. (2003). Legume symbiotic nitrogen fixation by $\beta$-proteobacteria is widespread in nature. J. Bacteriol. 185, 7266-7272. doi: 10.1128/JB.185.24.72667272.2003

Chimwamurombe, P. M., Grönemeyer, J. L., and Reinhold-Hurek, B. (2016). Isolation and characterization of culturable seed-associated bacterial endophytes from gnotobiotically grown Marama bean seedlings. FEMS Microbiol. Ecol. 92:fiw083. doi: 10.1093/femsec/fiw083

Christiansen-Weniger, C., Groneman, A. F., and van Veen, J. A. (1992). Associative $\mathrm{N}_{2}$ fixation and root exudation of organic acids from wheat cultivars of different aluminium tolerance. Plant Soil 139, 167-174. doi: 10.1007/BF0000 9307

Coelho, M. R., de Vos, M., Carneiro, N. P., Marriel, I. E., Paiva, E., and Seldin, L. (2008). Diversity of nifH gene pools in the rhizosphere of two cultivars of sorghum (Sorghum bicolor) treated with contrasting levels of nitrogen fertilizer. FEMS Microbiol. Lett. 279, 15-22. doi: 10.1111/j.1574-6968.2007. 00975.x

Compant, S., Gangl, H., and Sessitsch, A. (2013). "Visualization of niches of colonization of firmicutes with Bacillus spp. in the rhizosphere, rhizoplane, and endorhiza of grapevine plants at flowering stage of development by FISH microscopy," in Molecular Microbial Ecology of the Rhizosphere, Vol. 1-2 ed. F. J. de Bruijn (Hoboken, NJ: John Wiley \& Sons, Inc), doi: 10.1002/9781118297674. $\operatorname{ch} 39$

Compant, S., Mitter, B., Colli-Mull, J. G., Gangl, H., and Sessitsch, A. (2011). Endophytes of grapevine flowers, berries, and seeds: identification of cultivable bacteria, comparison with other plant parts, and visualization of niches of colonization. Microb. Ecol. 62, 188-197. doi: 10.1007/s00248-011-9883-y

Curatti, L., and Rubio, L. M. (2014). Challenges to develop nitrogen-fixing cereals by direct nif-gene transfer. Plant Sci 225, 130-37. doi: 10.1016/j.plantsci.2014. 06.003

Dalmastri, C., Chiarini, L., Cantale, C., Bevivino, A., and Tabacchioni, S. (1999). Soil type and maize cultivar affect the genetic diversity of maize root-associated Burkholderia cepacia populations. Microb. Ecol. 38, 273-284. doi: 10.1007/ s002489900177

Davidson, F. W., Whitney, H. G., and Tahlan, K. (2015). Genome sequences of Klebsiella variicola isolates from dairy animals with bovine mastitis from Newfoundland, Canada. Genome Announc. 3:e00938-15. doi: 10.1128/ genomeA.00938-15

Delaux, P. M., Radhakrishnan, G., and Oldroyd, G. (2015). Tracing the evolutionary path to nitrogen-fixing crops. Curr. Opin. Plant Biol. 26, 95-99. doi: 10.1016/j.pbi.2015.06.003 
Díaz Herrera, S., Grossi, C., Zawoznik, M., and Groppa, M. D. (2016). Wheat seeds harbour bacterial endophytes with potential as plant growth promoters and biocontrol agents of Fusarium graminearum. Microbiol. Res. 18, 37-43. doi: 10.1016/j.micres.2016.03.002

Elbeltagy, A., and Ando, Y. (2008). Expression of nitrogenase gene (nifH) in roots and stems of rice, Oryza sativa, by endophytic nitrogen-fixing communities. Afr. J. Biotechnol. 7, 1950-1957. doi: 10.5897/AJB2008.000-5042

Elbeltagy, A., Nishioka, K., Sato, T., Suzuki, H., Ye, B., Hamada, T., et al. (2001). Endophytic colonization and in planta nitrogen fixation by a Herbaspirillum sp. isolated from wild rice species. Appl. Environ. Microbiol. 67, 5285-5293. doi: 10.1128/AEM.67.11.5285-5293.2001

Engelhard, M., Hurek, T., and Reinhold-Hurek, B. (2000). Preferential occurrence of diazotrophic endophytes, Azoarcus spp., in wild rice species and land races of Oryza sativa in comparison with modern races. Environ. Microbiol. 2, 131-141. doi: 10.1046/j.1462-2920.2000.00078.x

Erisman, J. W., Sutton, M. A., Galloway, J., Klimont, Z., and Winiwarter, W. (2008). How a century of ammonia synthesis changed the world. Nat. Geosci. 1, 636-639. doi: 10.1038/ngeo325

Estrada-de los Santos, P., Vinuesa, P., Martínez-Aguilar, L., Hirch, A. M., and Caballero-Mellado, J. (2013). Phylogenetics analysis of Burkholderia species by multilocus sequence analysis. Curr. Microbiol. 67, 51-60. doi: 10.1007/s00284013-0330-9

Fiore, A., Laevens, S., Bevivino, A., Dalmastric, C., Tabacchioni, S., Vandamme, P., et al. (2001). Burkholderia cepacia complex: distribution of genomovars among isolates from the maize rhizosphere in Italy. Environ. Microbiol. 3, 137-143. doi: 10.1046/j.1462-2920.2001.00175.x

Fischer, D., Pfitzner, B., Schmid, M., Simões-Araújo, J. L., Reis, V. M., Pereira, W., et al. (2012). Molecular characterization of the diazotrophic bacterial community in uninoculated and inoculated field-grown sugarcane (Saccharum sp.). Plant Soil 356, 83-99. doi: 10.1007/s11104-011-0812-0

Fouts, D. E., Tyler, H. L., DeBoy, R. T., Daugherty, S., Ren, Q., Badger, J. H., et al. (2008). Complete genome sequence of the $\mathrm{N}_{2}$-fixing broad host range endophyte Klebsiella pneumoniae 342 and virulence predictions verified in mice. PLoS Genet. 4:e1000141. doi: 10.1371/journal.pgen.1000141

Fox, A. R., Soto, G., Valverde, C., Russo, D., Lagares, A. Jr., Zorreguieta, A., et al. (2016). Major cereal crops benefit from biological nitrogen fixation when inoculated with the nitrogen-fixing bacterium Pseudomonas protegens Pf-5 X940. Environ. Microbiol. 18, 3522-3534. doi: 10.1111/1462-2920. 13376

Friesen, M. L., Porter, S. S., Stark, S. C., von Wettberg, E. J., Sachs, J. L., and Martínez-Romero, E. (2011). Microbially mediated plant functional traits. Annu. Rev. Ecol. Evol. Syst. 42, 23-46. doi: 10.1146/annurev-ecolsys-102710145039

Fürnkranz, M., Lukesch, B., Müller, H., Huss, H., Grube, M., Berg, G., et al. (2012). Microbial diversity inside pumpkins: microhabitat-specific communities display a high antagonistic potential against phytopathogens. Microb. Ecol 63, 418-428. doi: 10.1007/s00248-011-9942-4

Geddes, B. A., Ryu, M. H., Mus, F., Garcia Costas, A., Peters, J. W., Voigt, C. A., et al. (2015). Use of plant colonizing bacteria as chassis for transfer of N2fixation to cereals. Curr. Opin. Biotechnol. 32, 216-222. doi: 10.1016/j.copbio. 2015.01.004

Gibson, A. H. (1966). The carbohydrate requirement for symbiotic nitrogen fixation: a "whole plant" growth analysis approach. Aust. J. Biol. Sci. 19, 499-515. doi: 10.1071/BI9660499

Gillis, M., Tran Van, V., Bardin, R., Goor, M., Hebbar, P., Willems, A., et al. (1995). Polyphasic taxonomy in the genus Burkholderia leading to an amended description of the genus and proposition of Burkholderia vietnamiensis sp. Nov. for $\mathrm{N}_{2}$-fixing isolates from rice in Vietnam. Int. J. Syst. Bacteriol. 45, 274-289. doi: 10.1099/00207713-45-2-274

Gomes, N. C. M., Heuer, H., Schönfeld, J., Costa, R., Mendonça-Hagler, L., and Smalla, K. (2001). Bacterial diversity of the rhizosphere of maize (Zea mays) grown in tropical soil studied by temperature gradient gel electrophoresis. Plant Soil 232, 167-180. doi: 10.1023/A:1010350406708

González-Pasayo, R., and Martínez-Romero, E. (2000). Multiresistance genes of Rhizobium etli CFN42. Mol. Plant Microbe Interact. 13, 572-577. doi: 10.1094/ MPMI.2000.13.5.572

Govedarica, M. (1990). Specific relationship between Beijerinckia Derx strains and some maize hybrids. Zemljište Biljka 39, 125-132.
Govindarajan, M., Balandreau, J., Muthukumarasamy, R., Revathi, G., and Lakshminarasimhan, C. (2006). Improved yield of micropropagated sugarcane following inoculation by endophytic Burkholderia vietnamiensis. Plant Soil 280, 239-252. doi: 10.1007/s11104-005-3223-2

Guntli, D., Heeb, M., Moënne-Loccoz, Y., and Défago, G. (1999). Contribution of calystegine catabolic plasmid to competitive colonization of the rhizosphere of calystegine-producing plants by Sinorhizobium meliloti Rm41. Mol. Ecol. 8, 855-863. doi: 10.1046/j.1365-294X.1999.00640.x

Guo, B., Wang, Y., Sun, X., and Tang, K. (2008). Bioactive natural products from endophytes: a review. Prikl. Biokhim. Mikrobiol. 44, 153-158. doi: 10.1134/ S0003683808020026

Gutiérrez-Zamora, M. L., and Martínez-Romero, E. (2001). Natural endophytic association between Rhizobium etli and maize (Zea mays L.). J. Biotechnol. 91, 117-126. doi: 10.1016/s0168-1656(01)00332-7

Gutjahr, C., Banba, M., Croset, V., An, K., Miyao, A., An, G., et al. (2008). Arbuscular mycorrhiza-specific signaling in rice transcends the common symbiosis signaling pathway. Plant Cell 20, 2989-3005. doi: 10.1105/tpc.108. 062414

Haichar, F. Z., Marol, C., Berge, O., Rangel-Castro, J. I., Prosser, J. I., Balesdent, J., et al. (2008). Plant host habitat and root exudates shape soil bacterial community structure. ISME J. 2, 1221-1230. doi: 10.1038/ismej.2008.80

Han, J., Song, Y., Liu, Z., and Hu, Y. (2011). Culturable bacterial community analysis in the root domains of two varieties of tree peony (Paeonia ostii). FEMS Microbiol. Lett. 322, 15-24. doi: 10.1111/j.1574-6968.2011.02319.x

Hardoim, P. R., Hardoim, C. C. P., van Overbeek, L. S., and van Elsas, J. D. (2012). Dynamics of seed-borne rice endophytes on early plant growth stages. PLoS One 7:e30438. doi: 10.1371/journal.pone.0030438

Hartmann, A., Schmid, M., van Tuinen, D., and Berg, G. (2009). Plant-driven selection of microbes. Plant Soil 321, 235-257. doi: 10.1007/s11104-008-9814-y

Hurek, T., Handley, L. L., Reinhold-Hurek, B., and Piché, Y. (2002). Azoarcus grass endophytes contribute fixed nitrogen to the plant in an unculturable state. Mol. Plant Microbe Interact. 15, 233-242. doi: 10.1094/MPMI.2002.15.3.233

Isobe, K., and Ohte, N. (2014). Ecological perspectives on microbes involved in N-cycling. Microbes Environ. 29, 4-16. doi: 10.1264/jsme2.ME13159

Ivleva, N. B., Groat, J., Staub, J. M., and Stephens, M. (2016). Expression of active subunit of nitrogenase via integration into plant organelle genome. PLoS One 11:e0160951. doi: 10.1371/journal.pone.0160951

James, E. K., Gyaneshwar, P., Mathan, N., Barraquio, W. L., Reddy, P. M., Iannetta, P. P., et al. (2002). Infection and colonization of rice seedlings by the plant growth-promoting bacterium Herbaspirillum seropedicae Z67. Mol. Plant Microbe Interact. 15, 894-906. doi: 10.1094/MPMI.2002.15.9.894

Johnston-Monje, D., Mousa, W. K., Lazarovits, G., and Raizada, M. N. (2014). Impact of swapping soils on the endophytic bacterial communities of predomesticated, ancient and modern maize. BMC Plant Biol. 14:233. doi: 10.1186/ s12870-014-0233-3

Johnston-Monje, D., and Raizada, M. N. (2011). Conservation and diversity of seed associated endophytes in Zea across boundaries of evolution, ethnography and ecology. PLoS One 6:e20396. doi: 10.1371/journal.pone. 0020396

Kennedy, I. R., Choudhury, A. T. M. A., and Kecskés, M. L. (2004). Non-symbiotic bacterial diazotrophs in crop-farming systems: can their potential for plant growth promotion be better exploited? Soil Biol. Biochem. 36, 1229-1244. doi: 10.1016/j.soilbio.2004.04.006

Kennedy, I. R., and Cocking, E. C. (1997). Biological Nitrogen Fixation: The Global Challenge and Future Needs. Sydney: SUNFix Press.

Khalaf, E. M., and Raizada, M. N. (2016). Taxonomic and functional diversity of cultured seed associated microbes of the cucurbit family. BMC Microbiol. 16:131. doi: 10.1186/s12866-016-0743-2

Khush, G. S., and Bennett, J. (eds) (1992). Nodulation and Nitrogen Fixation in Rice: Potential and Prospects. Manila: IRRI International Rice Research Institute.

Knief, C., Delmotte, N., Chaffron, S., Stark, M., Innerebner, G., Wassmann, R., et al. (2012). Metaproteogenomic analysis of microbial communities in the phyllosphere and rhizosphere of rice. ISME J. 6, 1378-1390. doi: 10.1038/ismej. 2011.192

Krause, A., Ramakumar, A., Bartels, D., Battistoni, F., Bekel, T., Boch, J., et al. (2007). Complete genome of the mutualistic $\mathrm{N}_{2}$-fixing grass endophyte Azoarcus sp. strain BH72. Nat. Biotech. 25:478. doi: 10.1038/ nbt1243 
Kutter, S., Hartmann, A., and Schmid, M. (2006). Colonization of barley (Hordeum vulgare) with Salmonella enterica and Listeria spp. FEMS Microbiol. Ecol. 56, 262-271. doi: 10.1111/j.1574-6941.2005.00053.x

Ladha, J. K., and Reddy, P. M. (eds) (2000). "The quest for nitrogen fixation in rice," in Proceedings of the 3rd Working Group Meeting on Assessing Opportunities for Nitrogen Fixation in Rice, (Makati: International Rice Research Institute), 354.

Ladha, J. K., and Reddy, P. M. (1995). Extension of nitrogen fixation to rice Necessity and possibilities. Geo J. 35, 363-372. doi: 10.1007/BF00989144

Layzell, D. B. (2000). "Carbon costs for endosymbiotic nitrogen fixation in legumes," in Proceedings of the 3rd Working Group Meeting on Assessing Opportunities for Nitrogen Fixation in Rice, eds J. K. Ladha and P. M. Reddy (Makati: International Rice Research Institute,), 341-342.

Lebeis, S. L., Paredes, S. H., Lundberg, D. S., Breakfield, N., Gehring, J., McDonald, M., et al. (2015). Plant Microbiome. Salicylic acid modulates colonization of the root microbiome by specific bacterial taxa. Science 349, 860-864. doi: 10.1126/science.aaa8764

Li, X., Rui, J., Xiong, J., Li, J., He, Z., Zhou, J., et al. (2014). Functional potential of soil microbial communities in the maize rhizosphere. PLoS One 9:e112609. doi: 10.1371/journal.pone.0112609

Liu, H., Carvalhais, L. C., Crawford, M., Singh, E., Dennis, P. G., Pieterse, C. M. J., et al. (2017a). Inner plant values: diversity, colonization and benefits from endophytic bacteria. Front. Microbiol. 8:2552. doi: 10.3389/fmicb.2017. 02552

Liu, H., Zhang, L., Meng, A., Zhang, J., Xie, M., Qin, Y., et al. (2017b). Isolation and molecular identification of endophytic diazotrophs from seeds and stems of three cereal crops. PLoS One 12:e0187383. doi: 10.1371/journal.pone.0187383

López, J. L., Alvarez, F., Príncipe, A., Salas, M. E., Lozano, M. J., Draghi, W. O., et al. (2018). Isolation, taxonomic analysis, and phenotypic characterization of bacterial endophytes present in alfalfa (Medicago sativa) seeds. J. Biotechnol. 267, 55-62. doi: 10.1016/j.jbiotec.2017.12.020

López-Guerrero, M., Ramírez, M. A., and Martínez-Romero, E. (2013). "Rhizobial genetic repertoire to inhabit legume and nonlegume rhizospheres," in Molecular Microbial Ecology of the Rhizosphere, Vol. 1 2, ed. F. J. de Bruijn (Hoboken, NJ: John Wiley \& Sons, Inc), doi: 10.1002/9781118297674.ch46

López-López, A., Negrete-Yankelevich, S., Rogel, M. A., Ormeño-Orrillo, E., Martínez, J., and Martínez-Romero, E. (2012). Native bradyrhizobia from Los Tuxtlas in Mexico are symbionts of Phaseolus lunatus (Lima bean). Syst. Appl. Microbiol. 36, 33-38. doi: 10.1016/j.syapm.2012.10.006

López-Torrejón, G., Jiménez-Vicente, E., Buesa, J. M., Hernandez, J. A., Verma, H. K., and Rubio, L. M. (2016). Expression of a functional oxygen-labile nitrogenase component in the mitochondrial matrix of aerobically grown yeast. Nat. Commun. 7:11426. doi: 10.1038/ncomms11426

Lundberg, D. S., Lebeis, S. L., Paredes, S. H., Yourstone, S., Gehring, J., Malfatti, S., et al. (2012). Defining the core Arabidopsis thaliana root microbiome. Nature 488, 86-90. doi: 10.1038/nature11237

Lynch, J. M., and Whipps, J. M. (1990). Substrate flow in the rhizosphere. Plant Soil 129, 1-10. doi: 10.1007/BF00011685

Madmony, A., Chernin, L., Pleban, S., Peleg, E., and Riov, J. (2005). Enterobacter cloacae, an obligatory endophyte of pollen grains of Mediterranean pines. Folia Microbiol. 50, 209-216. doi: 10.1007/BF02931568

Markmann, K., and Parniske, M. (2008). Evolution of root endosymbiosis with bacteria: How novel are nodules? Trends Plant Sci. 14, 77-86. doi: 10.1016/j. tplants.2008.11.009

Mårtensson, L., Díez, B., Wartiainen, I., Zheng, W., El-Shehawy, R., and Rasmussen, U. (2009). Diazotrophic diversity, nifH gene expression and nitrogenase activity in a rice paddy field in Fujian, China. Plant Soil 325, 207-218. doi: 10.1007/s11104-009-9970-8

Martínez, J., Martínez, L., Rosenblueth, M., Silva, J., and Martínez-Romero, E. (2004). How are gene sequence analyses modifying bacterial taxonomy? The case of Klebsiella. Int. Microbiol. 7, 261-268.

Martínez, L., Caballero, J., Orozco, J., and Martínez-Romero, E. (2003). Diazotrophic bacteria associated with banana (Musa spp.). Plant Soil 257, 35-47. doi: 10.1023/A:1026283311770

Martínez-Romero, E., Rodríguez-Medina, N., Beltrán-Rojel, M., ToribioJiménez, J., and Garza-Ramos, U. (2018). Klebsiella variicola and Klebsiella quasipneumoniae with capacity to adapt to clinical and plant settings. Salud Pública Méx. 60, 29-40. doi: 10.21149/8156
Martínez-Romero, E., Silva-Sanchez, J., Barrios, H., Rodríguez-Medina, N., Martínez-Barnetche, J., Téllez-Sosa, J., et al. (2015). Draft genome sequences of Klebsiella variicola plant isolates. Genome Announc. 3:e01015-15. doi: 10.1128/ genomeA.01015-15

Matiru, V. N., and Dakora, F. D. (2004). Potential use of rhizobial bacteria as promoters of plant growth for increased yield in landraces of African cereal crops. African J. Biotechnol. 3, 1-7. doi: 10.5897/AJB2004.000-2002

Mendes, R., Garbeva, P., and Raaijmakers, J. M. (2013). The rhizosphere microbiome: significance of plant beneficial, plant pathogenic, and human pathogenic microorganisms. FEMS Microbiol. Rev. 37, 634-663. doi: 10.1111/ 1574-6976.12028

Mendes, R., Pizzirani-Kleiner, A. A., Araujo, W. L., and Raaijmakers, J. M. (2007). Diversity of cultivated endophytic bacteria from sugarcane: genetic and biochemical characterization of Burkholderia cepacia complex isolates. Appl. Environ. Microbiol. 72, 7259-7267. doi: 10.1128/AEM.01222-07

Merino-Flores, M. (2012). Diversidad Bacteriana de la Rizósfera de Maíz Regado Con Agua Del Río Apatlaco Mediante un Enfoque Independiente De Cultivo (Búsqueda de Micobacterias). Ph.D. thesis, Universidad Autónoma del Estado de Morelos, Cuernavaca.

Mitter, B., Pfaffenbichler, N., Flavell, R., Compant, S., Antonielli, L., Petric, A., et al. (2017). A New approach to modify plant microbiomes and traits by introducing beneficial bacteria at flowering into progeny seeds. Front. Microbiol. 8:11. doi: $10.3389 /$ fmicb.2017.00011

Molina, M. A., Ramos, J. L., and Espinosa-Urgel, M. (2006). A two-partner secretion system is involved in seed and root colonization and iron uptake by Pseudomonas putida KT2440. Environ. Microbiol. 8, 639-647. doi: 10.1111/j. 1462-2920.2005.00940.x

Morris, J. J., Lenski, R. E., and Zinser, E. R. (2012). The black queen hypothesis: evolution of dependencies through adaptive gene loss. mBio. 3:e00036-12. doi: $10.1128 / \mathrm{mBio} .00036-12$

Mus, F., Crook, M. B., Garcia, K., Garcia Costas, A., Geddes, B. A., Kouri, E. D., et al. (2016). Symbiotic nitrogen fixation and the challenges to its extension to nonlegumes. Appl. Environ. Microbiol. 82, 3698-3710. doi: 10.1128/AEM. 01055- 16

Muthukumarasamy, R., Cleenwerck, I., Revathi, G., Vadivelu, M., Janssens, D., Hoste, B., et al. (2005). Natural association of Gluconacetobacter diazotrophicus and diazotrophic Acetobacter peroxydans with wetland rice. Syst. Appl. Microbiol. 28, 277-286. doi: 10.1016/j.syapm.2005.01.006

Okon, Y., and Itzigsohn, R. (1995). The development of Azospirillum as a commercial inoculant for improving crop yields. Biotechnol. Adv. 13, 415-424. doi: 10.1016/0734-9750(95)02004-M

Okunishi, S., Sako, K., Mano, H., Imamura, A., and Morisaki, H. (2005). Bacterial flora of endophytes in the maturing seed of cultivated rice (Oryza sativa). Microbes Environ. 20, 168-177. doi: 10.1264/jsme2.20.168

Ormeño-Orrillo, E., Hungria, M., and Martínez-Romero, E. (2013). "Dinitrogen-fixing prokaryotes," in The Prokaryotes: Prokaryotic Physiology and Biochemistry, eds E. Rosenberg, E. F. de Long, S. Lory, E. Stackebrandt, and F. Thompson (Berlin: Springer-Verlag), 427-451. doi: 10.1007/978-3-642-30141-4_72

Pankievicz, V. C., Camilios-Neto, D., Bonato, P., Balsanelli, E., Tadra-Sfeir, M. Z., Faoro, H., et al. (2016). RNA-seq transcriptional profiling of Herbaspirillum seropedicae colonizing wheat (Triticum aestivum) roots. Plant Mol. Biol. 90, 589-603. doi: 10.1007/s11103-016-0430-6

Parniske, M., Ahlborn, B., and Werner, D. (1991). Isoflavonoid-inducible resistance to the phytoalexin glyceollin in soybean rhizobia. J. Bacteriol. 173, 3432-3439. doi: $10.1128 /$ jb.173.11.3432-3439.1991

Pate, J. S., Layzell, D. B., and Atkins, C. A. (1979). Economy of carbon and nitrogen in a nodulated and non-nodulated $\left(\mathrm{NO}_{3}\right.$-grown) legume. Plant Physiol. 64, 1083-1088. doi: 10.1104/pp.64.6.1083

Paul, M. J., and Foyer, C. H. (2001). Sink regulation of photosynthesis. J. Exp. Bot. 52, 1383-1400. doi: 10.1093/jexbot/52.360.1383

Pedrosa, F. O., Monteiro, R. A., Wassem, R., Cruz, L. M., Ayub, R. A., Colauto, N. B., et al. (2011). Genome of Herbaspirillum seropedicae strain SmR1, a specialized diazotrophic endophyte of tropical grass. PLoS Gentet. 7:e1002064. doi: 10.1371/journal.pgen.1002064

Peiffer, J. A., Spor, A., Koren, O., Jin, Z., Tringe, S. G., Dangl, J. L., et al. (2013). Diversity and heritability of the maize rhizosphere microbiome under field 
conditions. Proc. Natl. Acad. Sci. U.S.A. 110, 6548-6553. doi: 10.1073/pnas. 1302837110

Peralta, H., Aguilar, A., Díaz, R., Mora, Y., Martínez-Batallar, G., Salazar, E., et al. (2016). Genomic studies of nitrogen-fixing rhizobial strains from Phaseolus vulgaris seeds and nodules. BMC Genomics 17:711. doi: 10.1186/s12864-0163053-z

Pereira, P., Ibáñez, F., Rosenblueth, M., Etcheverry, M., and Martínez-Romero, E. (2011). Analysis of the bacterial diversity associated with the roots of maize (Zea mays L.) by culture dependent and culture independent methods. ISRN Ecol. 2011:938546. doi: 10.5402/2011/938546

Perin, L., Martínez-Aguilar, L., Castro-González, R., Estrada-de Los Santos, P., Cabellos-Avelar, T., Guedes, H. V., et al. (2006). Diazotrophic Burkholderia species associated with field-grown maize and sugarcane. Appl. Environ. Microbiol. 72, 3103-3110. doi: 10.1128/AEM.72.5.3103-3110.2006

Pfeiffer, B., Fender, A.-C., Lasota, S., Hertel, D., Jungkunst, H. F., and Daniel, R. (2013). Leaf litter is the main driver for changes in bacterial community structures in the rhizosphere of ash and beech. Appl. Soil Ecol. 72, 150-160. doi: 10.1016/j.apsoil.2013.06.008

Pfeiffer, S., Mitter, B., Oswald, A., Schloter-Hai, B., Schloter, M., Declerck, S., et al. (2017). Rhizosphere microbiomes of potato cultivated in the High Andes show stable and dynamic core microbiomes with different responses to plant development. FEMS Microbiol. Ecol. 93:fiw242. doi: 10.1093/femsec/fiw242

Pracht, J. E., Nickell, C. D., Harper, J. E., and Bullock, D. G. (1994). Agronomic evaluation of non-nodulating and hypernodulating mutants of soybean. Crop Sci. 34, 738-740. doi: 10.2135/cropsci1994.0011183X003400030025x

Rangjaroen, C., Rerkasem, B., Teaumroong, N., Sungthong, R., and Lumyong, S. (2014). Comparative study of endophytic and endophytic diazotrophic bacterial communities across rice landraces grown in the highlands of northern Thailand. Arch. Microbiol. 196, 35-49. doi: 10.1007/s00203-013-0940-4

Ray, D. K., Mueller, N. D., West, P. C., and Foley, J. A. (2013). Yield trends are insufficient to double global crop production by 2050. PLoS One 8:e66428. doi: 10.1371/journal.pone.0066428

Reddy, P. M., Altúzar-Molina, A. R., Ortiz-Berrocal, M., Medina-Andrés, R., López-Sámano, M., Martínez-Aguilar, L., et al. (2013). "Predisposition and redesigning of genetic networks of rice for accommodating nitrogen-fixing rhizobial symbiosis," in International Dialogue on Perception and Prospects of Designer Rice, eds K. Muralidharan and E. A. Siddiq (Hyderabad: Society for Advancement of Rice Research), 245-257.

Reddy, P. M., James, E. K., and Ladha, J. K. (2002). "Nitrogen fixation in rice," in Nitrogen Fixation at the Millennium, ed. G. J. Leigh (Amsterdam: Elsevier), 421-445. doi: 10.1016/B978-044450965-9/50015-X

Reinhold-Hurek, B., and Hurek, T. (1997). Azoarcus spp. and their interactions with grass roots. Plant Soil 194, 57-64. doi: 10.1023/A:1004216507507

Reyna-Flores, F., Barrios-Camacho, H., Dantán-González, E., Ramírez-Trujillo, J. A., Lozano Aguirre Beltrán, L. F., Rodríguez-Medina, N., et al. (2018). Draft genome sequences of endophytic isolates of Klebsiella variicola and Klebsiella pneumoniae obtained from the same sugarcane plant. Genome Announc. 6:e00147-18. doi: 10.1128/genomeA.00147-18

Rijavec, T., Lapange, A., Dermastia, M., and Rupnik, M. (2007). Isolation of bacterial endophytes from germinated maize kernels. Can. J. Microbiol. 53, 802-808. doi: 10.1139/W07-048

Roesch, L. F. W., Camargo, F. A. O., Bento, F. M., and Triplett, E. W. (2008). Biodiversity of diazotrophic bacteria within the soil, root and stem of fieldgrown maize. Plant Soil 302, 91-104. doi: 10.1007/s11104-007-9458-3

Rogers, C., and Oldroyd, G. E. D. (2014). Synthetic biology approaches to engineering the nitrogen symbiosis in cereals. J. Exp. Bot. 65, 1939-1946. doi: $10.1093 / \mathrm{jxb} / \mathrm{eru} 098$

Roncato-Maccari, L. D., Ramos, H. J., Pedrosa, F. O., Alquini, Y., Chubatsu, L. S., Yates, M. G., et al. (2003). Endophytic Herbaspirillum seropedicae expresses nif genes in gramineous plants. FEMS Microbiol. Ecol. 45, 39-47. doi: 10.1016/ S0168-6496(03)00108-9

Rosenblueth, M., López-López, A., Martínez, J., Rogel, M. A., Toledo, I., and Martínez Romero, E. (2012). Seed bacterial endophytes: common genera, seed to seed variability and possible roles in plants. Acta Hortic. 938, 39-48. doi: 10.17660/ActaHortic.2012.938.4

Rosenblueth, M., Martínez, L., Silva, J., and Martínez-Romero, E. (2004). Klebsiella variicola, a novel species with clinical and plant-associated isolates. Syst. Appl. Microbiol. 27, 27-35. doi: 10.1078/0723-2020-00261
Rosenblueth, M., and Martínez-Romero, E. (2004). Rhizobium etli maize populations and their competitiveness for root colonization. Arch. Microbiol. 181, 337-344. doi: 10.1007/s00203-004-0661-9

Rosenblueth, M., and Martínez-Romero, E. (2006). Bacterial endophytes and their interactions with hosts. Mol. Plant Microbe Interact. 19, 827-837. doi: 10.1094/ MPMI-19-0827

Rosenblueth, M., Martínez-Romero, J. C., Reyes-Prieto, M., Rogel, M. A., and Martínez-Romero, E. (2011). Environmental mycobacteria: a threat to human health? DNA Cell Biol. 30, 633-640. doi: 10.1089/dna.2011.1231

Rossbach, S., McSpadden, B., Kulpa, D., Rasul, G., Ganoof, M., and de Bruijn, F. J. (1994). Use of rhizopine synthesis and catabolism genes to monitor soil bacteria and to create biased rhizospheres. Mol. Ecol. 3, 610-611.

Sachman-Ruiz, B., Castillo-Rodal, A. I., López-Vidal, Y., Martínez-Romero, E., and Vinuesa, P. (2009). "Diversity of environmental mycobacteria in Mexican rivers assessed by cultivation and metagenomic approaches," in Proceedings of the 109th General Meeting, Philadelphia, PA, 17-21.

Saharan, B., and Nehra, V. (2011). Plant growth promoting rhizobacteria: a critical review. Life Sci. Med. Res. 21, 1-30.

Santi, C., Bogusz, D., and Franche, C. (2013). Biological nitrogen fixation in non-legume plants. Ann. Bot. 111, 743-767. doi: 10.1093/aob/mc t048

Sawada, S., Hayakawa, T., Fukushi, K., and Kasai, M. (1986). Influence of carbohydrates on photosynthesis in single, rooted soybean leaves used as a source-sink model. Plant Cell Physiol. 27, 591-600.

Sawana, A., Adeolu, M., and Gupta, R. S. (2014). Molecular signatures and phylogenomics analysis of the genus Burkholderia: proposal for division of this genus into the emended genus Burkholderia containing pathogenic organisms and a new genus Paraburkholderia gen. nov. harboring environmental species. Front. Genet. 5:429. doi: 10.3389/fgene.2014.00429

Schmalenberger, A., and Tebbe, C. C. (2003). Bacterial diversity in maize rhizospheres: conclusions on the use of genetic profiles based on PCR-amplified partial small subunit rRNA genes in ecological studies. Mol. Ecol. 12, 251-262. doi: 10.1046/j.1365-294X.2003.01716.x

Setten, L., Soto, G., Mozzicafreddo, M., Fox, A. R., Lisi, C., Cuccioloni, M., et al. (2013). Engineering Pseudomonas protegens Pf- 5 for nitrogen fixation and its application to improve plant growth under nitrogen-deficient conditions. PLoS One 8:e63666. doi: 10.1371/journal.pone.0063666

Shahzad, R., Waqas, M., Khan, A. L., Asaf, S., Khan, M. A., Kang, S. M., et al. (2016). Seed-borne endophytic Bacillus amyloliquefaciens RWL-1 produces gibberellins and regulates endogenous phytohormones of Oryza sativa. Plant Physiol. Biochem. 106, 236-243. doi: 10.1016/j.plaphy.2016. 05.006

Sharkey, T. D., Stitt, M., Heineke, D., Gerhardt, R., Raschke, K., and Heldt, H. W. (1986). Limitation of photosynthesis by carbon metabolism: II. $\mathrm{O}_{2}$ insensitive $\mathrm{CO}_{2}$ uptake results from limitation of triose phosphate utilization. Plant Physiol. 81, 1123-1129. doi: 10.1104/pp.81.4.1123

Smil, V. (2002). Nitrogen and food production: proteins for human diets. Ambio 31, 126-131. doi: 10.1579/0044-7447-31.2.126

Song, L., Carroll, B. J., Gresshoff, P. M., and Herridge, D. F. (1995). Field assessment of supernodulating genotypes of soybean for yield, $\mathrm{N}_{2}$ fixation and benefit to subsequent crops. Soil Biol. Biochem. 27, 563-569. doi: 10.1016/0038-0717(95) 98632-X

Stacey, G., McAlvin, C. B., Kim, S. Y., Olivares, J., and Soto, M. J. (2006). Effects of endogenous salicylic acid on nodulation in the model legumes Lotus japonicus and Medicago truncatula. Plant Physiol. 141, 1473-1481. doi: 10.1104/pp.106. 080986

Stevenson, F. J., and Cole, M. A. (1999). Cycles of Soils: Carbon, Nitrogen, Phosphorus, Sulfur, Micronutrients. Hoboken, NJ: John Wiley \& Sons.

Stokstad, E. (2016). The nitrogen fix. Science 353, 1225-1227. doi: 10.1126/science. 353.6305 .1225

Terakado-Tonooka, J., Ohwaki, Y., Yamakawa, H., Tanaka, F., Yoneyama, T., and Fujihara, S. (2008). Expressed nifH genes of endophytic bacteria detected in field-grown sweet potatoes (Ipomoea batatas L.). Microbes Environ. 23, 89-93. doi: $10.1264 /$ jsme2.23.89

Thaweenut, N., Hachisuka, Y., Ando, S., Yanagisawa, S., and Yoneyama, T. (2011). Two seasons' study on nifH gene expression and nitrogen fixation by diazotrophic endophytes in sugarcane (Saccharum spp. hybrids): expression of nifH genes similar to 
those of rhizobia. Plant Soil 338, 435-449. doi: 10.1007/s11104-0100557-1

Triplett, E. W. (1996). Diazotrophic endophytes: progress and prospects for nitrogen fixation in monocots. Plant Soil 186, 29-38. doi: 10.1007/BF00035052

Ueda, T., Suga, Y., Yahiro, N., and Matsuguchi, T. (1995). Remarable $\mathrm{N}_{2}$-fixing bacterial diversity detected in rice roots by molecular evolutionary analysis of nifH gene sequences. J. Bacteriol. 177, 1414-1417. doi: 10.1128/jb.177.5.14141417.1995

Van Dommelen, A., Croonenborghs, A., Spaepen, S., and Vanderleyden, J. (2009). Wheat growth promotion through inoculation with an ammonium-excreting mutant of Azospirillum brasilense. Biol. Fertil. Soils 45, 549-553. doi: 10.1007/ s00374-009-0357-z

Vance, C. P., and Heichel, G. H. (1991). Carbon in $\mathrm{N}_{2}$ fixation: limitation or exquisite adaptation. Annu. Rev. Plant Physiol. Plant Mol. Biol. 42, 373-390. doi: 10.1146/annurev.pp.42.060191.002105

Venturi, V., and Keel, C. (2016). Signaling in the rhizosphere. Trends Plant Sci. 21, 187-198. doi: 10.1016/j.tplants.2016.01.005

Verma, S. K., Kingsley, K., Irizarry, I., Bergen, M., Kharwar, R. N., and White, J. F. Jr. (2017). Seed-vectored endophytic bacteria modulate development of rice seedlings. J. Appl. Microbiol. 122, 1680-1691. doi: 10.1111/jam. 13463

Vermeiren, H., Willems, A., Schoofs, G., de Mot, R., Keijers, V., Hai, W., et al. (1999). The rice inoculant strain Alcaligenes faecalis A15 is a nitrogen-fixing Pseudomonas stutzeri. Syst. Appl. Microbiol. 22, 215-224. doi: 10.1016/S07232020(99)80068-X

Wagner, M. R., Lundberg, D. S., Del Rio, T. G., Tringe, S. G., Dangl, J. L., and Mitchell-Olds, T. (2016). Host genotype and age shape the leaf and root microbiomes of a wild perennial plant. Nat. Commun. 7:12151. doi: 10.1038/ ncomms 12151

Wang, W., Zhai, Y., Cao, L., Tan, H., and Zhang, R. (2016). Illumina-based analysis of core actinobacteriome in roots, stems, and grains of rice. Microbiol. Res. 190, 12-18. doi: 10.1016/j.micres.2016.05.003

Wartiainen, I., Eriksson, T., Zheng, W., and Rasmussen, U. (2008). Variation in the active diazotrophic community in rice paddy-nifH PCR-DGGE analysis of rhizosphere and bulk soil. Appl. Soil Ecol. 39, 65-75. doi: 10.1016/j.apsoil.2007. 11.008

Xiaoe, Y., and Xi, S. (1991). Physiological effect of nitrate or ammonia top-dressing on hybrid and conventional rice varieties at late growth stage. Acta Agron. Sin. 17, 283-291.

Yanni, Y. G., Rizk, R. Y., Corich, V., Squartini, A., Ninke, K., PhilipHollingsworth, S., et al. (1997). Natural endophytic association between Rhizobium leguminosarum bv. trifolii and rice roots and assessment of its potential to promote rice growth. Plant Soil 194, 99-114. doi: 10.1023/A: 1004269902246

You, M., Nishiguchi, T., Saito, A., Isawa, T., Mitsui, H., and Minamisawa, K. (2005). Expression of the nifH gene of a Herbaspirillum endophyte in wild rice species: daily rhythm during the light-dark cycle. Appl. Environ. Microbiol. 71, 8183-8190. doi: 10.1128/AEM.71.12.8183-8190.2005

Zawoznik, M. S., Vázquez, S. C., Díaz Herrera, S. M., and Groppa, M. D. (2014). Search for endophytic diazotrophs in barley seeds. Braz. J. Microbiol. 45, 621-625. doi: 10.1590/S1517-83822014000200033

Zhang, T., Yan, Y., He, S., Ping, S., Alam, K. M., Han, Y., et al. (2012). Involvement of the ammonium transporter AmtB in nitrogenase regulation and ammonium excretion in Pseudomonas stutzeri A1501. Res. Microbiol. 163, 332-339. doi: 10.1016/j.resmic.2012.05.002

Conflict of Interest Statement: The authors declare that the research was conducted in the absence of any commercial or financial relationships that could be construed as a potential conflict of interest.

Copyright (C) 2018 Rosenblueth, Ormeño-Orrillo, López-López, Rogel, ReyesHernández, Martínez-Romero, Reddy and Martínez-Romero. This is an open-access article distributed under the terms of the Creative Commons Attribution License (CC BY). The use, distribution or reproduction in other forums is permitted, provided the original author(s) and the copyright owner(s) are credited and that the original publication in this journal is cited, in accordance with accepted academic practice. No use, distribution or reproduction is permitted which does not comply with these terms. 